\title{
Presence of Microorganisms and Use of Antimicrobial Agents in Car Seat Fabrics: A Brief Review
}

\author{
Mariane Fraga Dias Santana ${ }^{1}$, Jeancarlo Pereira dos Anjos ${ }^{1,2^{*}}$, Marcelo Pinheiro Fontes ${ }^{1}$, \\ Tatiana Barreto Rocha Nery ${ }^{1}$ \\ ${ }^{I}$ SENAI CIMATEC University Center; ${ }^{2} I N C T$ of Energy and Environment, UFBA; Salvador, BA, Brazil
}

\begin{abstract}
The present paper discusses the presence of microorganisms in textile materials, especially in car seats, and the use of antimicrobial agents. We observed that the main agent between the user and the car's microbial system are the seats, due to the direct contact with the users. In addition, the environment in which the car is inserted, the type of car, and the seat fabric-type influence directly the reproduction of the microbial system. Microorganisms found in different parts of cars, especially in seats, could be potential threats to human health. Thus, to combat these microorganisms, it is necessary to study antimicrobial agents aimed at eliminating or inhibiting their reproduction and, consequently, promoting hygiene, ensuring the health and well-being of car users.
\end{abstract}

Keywords: Bacteria. Fungi. Textile. Automotive Seats. Antimicrobial Agents.

Abbreviations: Ag-NPs: silver nanoparticles; Cu-NPs: copper nanoparticles; NOX: oxidation number.

\section{Introduction}

In a globalized world, the need to constantly move has contributed to individuals spending more time inside the cars. The seat covering is the part of the car that the user has the most contact with, and this can have consequences on human microbial environment. The microbial systems present inside a car vary according to the circumstances in which it is inserted, type of car, the internal composition, and principally with the structural organization of the fabric, which is pointed out as good substrates for the development of microorganisms $[1,2]$.

The most used fabrics for the manufacture of automotive seats are leather, synthetic leather, looms, and knitwear. The structural organization of the fabric is related to the absorption of water, oxygen, and nutrients, which makes the fabrics of natural fibers and vegetables more susceptible to the proliferation of microorganisms $[1,3]$.

Received on 10 March 2021; revised 21 May 2021.

Address for correspondence: Dr. Jeancarlo Pereira dos Anjos. Avenida Orlando Gomes, 1845, Piatã, Zip Code: 41650-010, Salvador, BA, Brazil. Phone: +55 71 3879-5677. E-mail: jeancarlo.anjos@fieb.org.br.

J Bioeng. Tech. Appl. Health

2021;4(2):71-75.

(C) 2021 by SENAI CIMATEC. All rights reserved.
Moreover, there is a growing expectation around fabrics with antibacterial properties. These fabrics have the insertion of antimicrobial agents in the fabric structure, allowing the ability to prevent or inhibit the spread of microorganisms, being considered, respectively, as biocide or biostatic. The incorporation of the antimicrobial agents into fabrics varies according to its performance, type of fiber in the textile material, and the most susceptible microorganism to the fabric. The main antimicrobials that have been used in textile materials are the quaternary ammonium compounds, pyrithione of zinc, nitrogen compounds, silver nanoparticles, and copper nanoparticles. [4] However, there are still few papers that demonstrate the use and effectiveness of the use of antimicrobial agents in fabrics used in automotive seats.

Therefore, to provide greater safety to the health of car users, this paper aimed to carry out a brief literature review on aspects related to the presence of microorganisms inside vehicles, with an emphasis on automotive seats, as well as the use of antimicrobial agents to minimize the microbiological load on the seats.

The literature research was limited to a maximum period of 7 years and carried out in databases on sites such as Scielo and Science Direct. For the study, it was considered automotive fabrics, microorganisms present inside cars, and their 
respective impacts on human health. In addition, the application and action of antimicrobial agents in textile materials were considered. Thus, the keywords "fabric", microorganism" and "car" were used to identify papers related to the topic.

\section{Literature Search Results}

We observed that the most frequent fungi found in the internal air of a vehicle are Cladosporium sp., Penicillium sp., Aspergillus sp. and Alternariaem sp. [1]. Staphylococcus sp. and Propionibacterium acnes sp. have a considerable population in common areas of the car, showing up in large numbers on steering wheels, gear knob and area near the cupholder (Table 1).
These microorganisms are capable of colonizing inanimate objects commonly touched. Thus, the car inside becomes a favorable environment as a reservoir of these microorganisms $[1,3]$. Species of the genus Staphylococcus sp. are more pathogenic. These microorganisms can promote a variety of diseases, from skin infections to respiratory diseases $[5,6]$. In addition to this genus, there are Pseudomonas sp. bacteria, capable of causing lung diseases, in the bloodstream, in the heart valves, as well as ear diseases [7].

As for fungi, despite having about 250,000 species, only 200 of them are recognized as pathogenic. In general, the genera Cladosporium sp., Penicillium sp., Aspergillus sp. e Alternariaem sp. could be encountered on the vehicle inside

Table 1. The estimated relative amount of bacterial genera (\%) in car locations*.

\begin{tabular}{|c|c|c|c|c|c|c|c|c|c|c|c|c|c|}
\hline \multirow{2}{*}{ Genus } & \multicolumn{3}{|c|}{ Car 1} & \multicolumn{2}{|c|}{ Car 2} & \multicolumn{2}{|c|}{ Car 3} & \multicolumn{3}{|c|}{ Car 4} & \multicolumn{3}{|c|}{ Car 5} \\
\hline & $\mathbf{A}$ & B & C & B & C & B & C & $\mathbf{A}$ & B & C & $\mathbf{A}$ & B & C \\
\hline Staphylococcus sp. & 77.1 & 74.1 & 10.2 & 19.1 & 3.32 & 14 & 63.7 & 12.5 & 10.5 & 1.05 & 19.7 & 29.2 & 28.2 \\
\hline $\begin{array}{l}\text { Propionibacterium } \\
\text { acnes sp. }\end{array}$ & 9.72 & 17.5 & 3.5 & 7.44 & 0.5 & 6.04 & 2.75 & 22.6 & 8.53 & 0.06 & 21.3 & 17.4 & 0.08 \\
\hline Acidovorax sp. & 1.23 & 0.17 & 6.55 & 3.41 & 0 & 9.22 & 0.02 & 7.55 & 3.75 & 0 & 1.5 & 2.96 & 23.5 \\
\hline Streptococcus sp. & 1.02 & 0.07 & 4.17 & 7.3 & 0 & 12.5 & 5.49 & 5.8 & 0 & 0.06 & 9.93 & 13.2 & 5.15 \\
\hline Clostridium sp. & 0.15 & 1.16 & 0 & 14.3 & 0 & 3 & 0.11 & 0.23 & 13.1 & 0.03 & 1.79 & 5.67 & 1.93 \\
\hline Mycobacterium sp. & 0.22 & 0.01 & 0.39 & 0 & 0 & 0.09 & 0.12 & 0 & 38.0 & 0.05 & 0 & 0 & 0.13 \\
\hline Acinetobacter sp. & 0.64 & 1.32 & 0.57 & 1 & 0 & 2.61 & 0 & 1.66 & 0.21 & 0.01 & 9.06 & 1.48 & 3.22 \\
\hline Pseudomonas sp. & 0 & 1.02 & 0.03 & 3.2 & 0.08 & 2.18 & 0.68 & 1.79 & 0.02 & 0 & 0.05 & 0 & 5.6 \\
\hline
\end{tabular}

Source: Adapted from Stephenson and colleagues (2014) [3].

* A - Steering wheel. B - gearshift button. C - Area next to the cupholder.

and are considered opportunistic-infectious, as they only play the role of mild allergy sufferers. However, when in large quantities and with the individual's immune system weakened can cause serious respiratory problems $[8,9]$.

Due to the possibility of these microorganisms being found inside cars, it is of great importance to assess their presence in automotive seat fabric, which is the part of the vehicle in greater contact with users of this means of transport.

A car seat has different parts, such as a metal frame, plastic parts, and a textile covering. The textile coating is the part that the user has contact with for a longer time and it can be made up of different textile materials in its composition, such as fabrics, carpets, leather, and vinyl material. Among these materials, the fabric is the material that has the greatest superficial use in automotive seats and, in the automotive industry, synthetic fibers are mostly used. Synthetic fibers have a technological advantage over natural fibers as they are more resistant to the proliferation of microorganisms due to their hydrophobic nature. However, they have the disadvantage of retaining more moisture from perspiration, which can promote the development of microbial cultures on the surface of the automotive seat covering. Thus, car seat fabric can present unpleasant odors and 
a possibility of contamination of human skin in contact with these microorganisms [10].

So, the emergence of diseases from unwanted microorganisms on surfaces made it necessary the study the antimicrobial agents for the promotion of personal and collective hygiene. The forms of action of these agents can be through the establishment of new intermolecular interactions or, even, through the oxidation of the organic matter present in these organisms $[4,11]$. Among these products, there are ethyl alcohol, isopropyl alcohol, and quaternary ammonium salts that act in the denaturation of proteins of the microorganisms; phenols that act on the disruption of the outer membrane, inactivation of enzymatic systems, among others; chlorine derivatives and peroxides that are capable of oxidizing the microorganism's organic matter [11]. In addition, there are silver nanoparticles (Ag-NPs) and copper nanoparticles (Cu-NPs) $[12,13]$.

Some studies indicate that the antimicrobial activity of silver nanoparticles is related to the release of $\mathrm{Ag}^{+}$ions in the medium. Accordingly, an increase in its effect is observed when used in smaller volumes (particles with smaller sizes, in this case, nanoparticles), due to the increase in the contact surface. When used in low concentrations, silver does not have significant effects on the human body, but Ag-NPs have an antibacterial effect for Gram-positive and Gram-negative bacteria. A priori, the interactions between the negative charges present on the surface of the bacteria and the silver cations are fundamental for the bonds between these structures to occur; these ions promote the deactivation of cellular enzymes and, consequently, cell lysis (Figure 1) [12].

Copper nanoparticles work similarly to AgNPs. It also presents a relationship between the velocity and the contact surface of the nanoparticles in which smaller sizes are favored. Copper nanoparticles can change NOX (oxidation number) in a continuous process, which can lead to penetration into the cell membrane, causing dysfunction in this region, as well as in the cytoplasm (Figure 2) [13].

However, for the impregnation of these agents in textile materials, it is necessary to know how they work in the fabric. [4] This application is often done by the method of immersing the fabric in a solution containing the antimicrobial agent. The padding method (foulardage) is one of the most used in the textile industry where the immersion

Figure 1. Mechanism and toxicity of the silver nanoparticles in microorganisms.

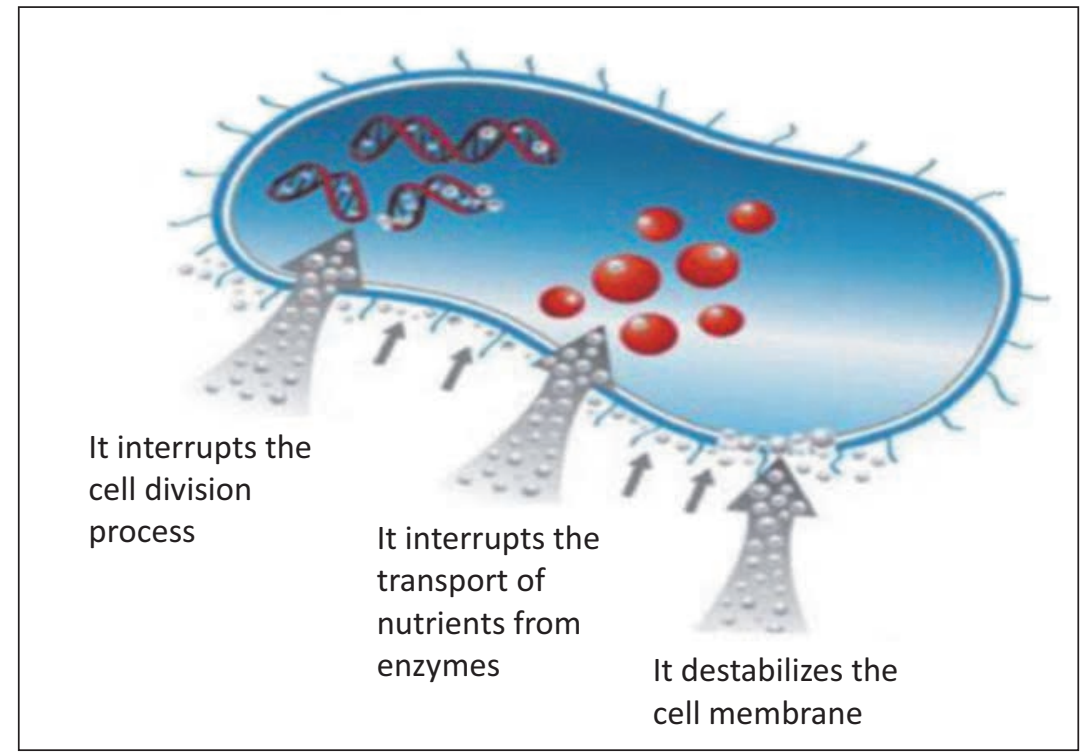

Source: Adapted from Benedito (2017) [14]. 
Figure 2. Mechanism and toxicity of the copper nanoparticles (Cu-NPs) in microorganisms.

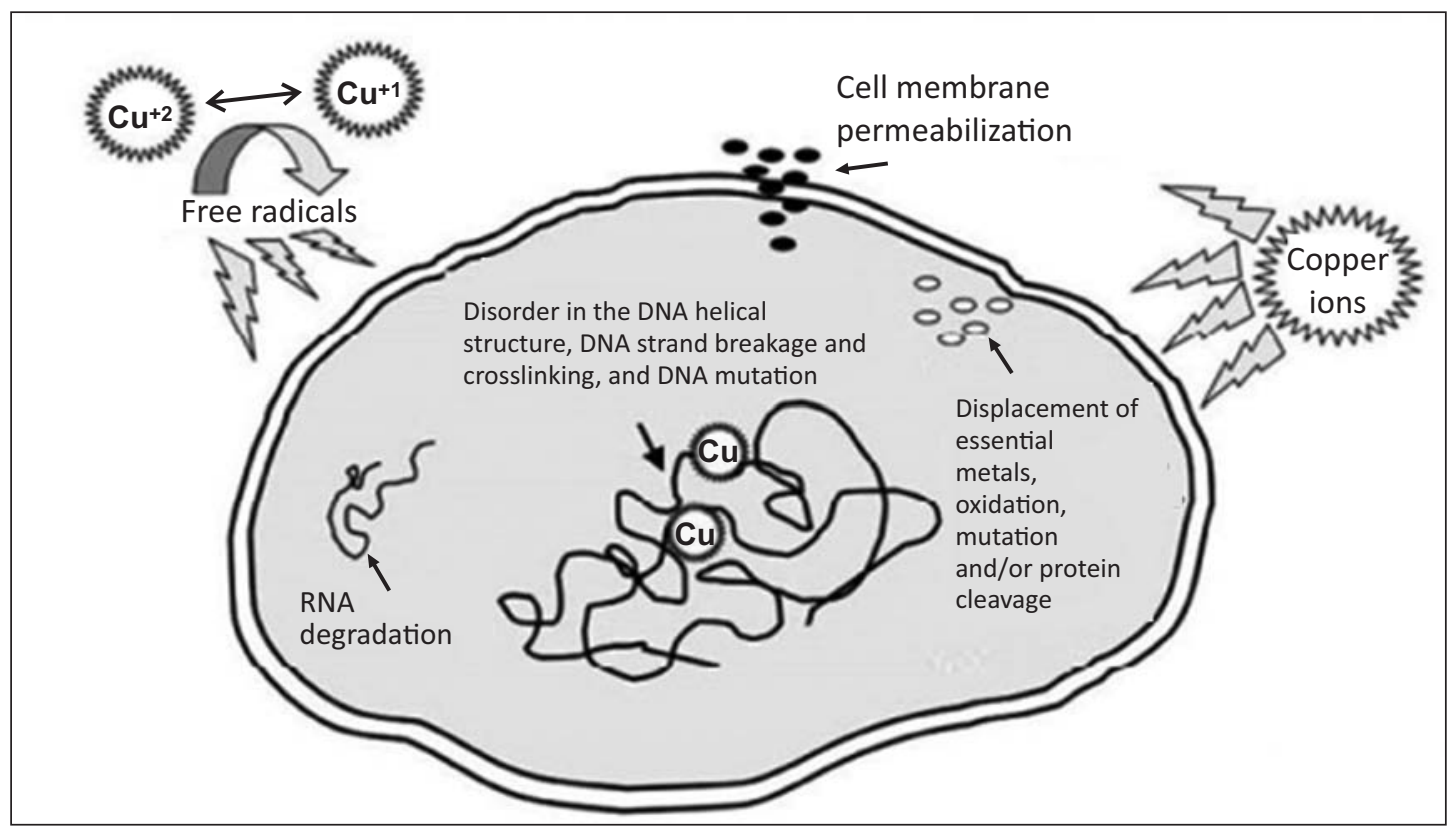

Source: Adapted from Ribeiro (2019) [13].

technique is used, however, a greater pressure of the agent is added to the fabric [15]. In chemical terms, antimicrobial agents can be inserted into the fabric by incorporation into the polymer matrix as well as by application to the fiber surface [4]. Table 2 shows different forms of interaction, for impregnation, between antimicrobial agents and fabric structure.
It is noteworthy that there is still little information in the literature about the nature of the microorganisms present in the car seat, as well as the use of antimicrobial agents to reduce the population of microbes in automotive fabrics.

Therefore, it is important to study the genera of the microorganisms present and the impregnation efficiency of antimicrobial agents

Table 2. Processes and connections between antimicrobial agents and a textile structure.

\begin{tabular}{|c|c|}
\hline Most common processes & Link between antimicrobial agent and textile structure \\
\hline $\begin{array}{l}\text { a) Addition of active compounds to the polymer matrix } \\
\text { b) Microencapsulation of the active ingredient and } \\
\text { addition to the polymer matrix }\end{array}$ & $\begin{array}{r}\text { Adsorbed on substrate } \\
\end{array}$ \\
\hline $\begin{array}{l}\text { c) Impregnation of active agents and fixation with resins } \\
\text { d) Coating application } \\
\text { e) Layer-by-layer application }\end{array}$ & Adsorbed to the surface \\
\hline $\begin{array}{l}\text { f) Chemical modification of fiber by introduction of } \\
\text { reactive groups and reaction with active agents } \\
\text { g) Chemical fiber modification by graft copolymerization } \\
\text { h) Active ingredient microencapsulation and fixation to } \\
\text { the fiber }\end{array}$ & \\
\hline
\end{tabular}

Source: Adapted from Scacchetti (2017) [4]. 
in fabrics, especially those used in automotive seat coverings. The reduction of the microbial load in the fabrics used in car seats can enable a reduction in the spread of diseases caused by different types of microorganisms, including bacteria, fungi, or viruses. It is noteworthy that more and more frequent car users are seeking greater health safety during the period they are traveling, especially in this period of the pandemic that the world is facing. Thus, this work showed different technologies that can be used in fabrics used in automotive seats to enable the use of antimicrobial agents, which have an action against different types of microorganisms that may be present inside vehicles.

\section{Conclusion}

It is possible to consider that automotive seats are significant sources for the spread of microorganisms, which can negatively influence the health of car users. Technological and scientific advances related to the study of antimicrobial agents have significantly contributed to the promotion of a less aggressive environment to human health.

Due to the limited research available on microorganisms in each type of fabric used in automotive seats, as well as evidence on the mechanism of action of some antimicrobial agents, this work shows the need for more detailed studies on the use and effectiveness of agents antimicrobials in fabrics used in car seat coverings.

\section{Acknowledgments}

The authors would like to thank the Conselho Nacional de Desenvolvimento Científico e Tecnológico (CNPq) and the Coordenação de Aperfeiçoamento de Pessoal de Nível Superior (CAPES).

\section{References}

1. Lee J, Jo W. Exposure to airborne fungi and bacteria while commuting in passenger cars and public buses. Atmospheric Environment 2016;39:7345-7348.

2. Coradi M. Têxteis antimicrobianos produzidos pela modificação superficial de tecidos de algodão e imobilização de enzima pectinolítica. 2018;32-38.

3. Stephenson R, Gutierrez D, Peters C, Nichols M, Boles B. Elucidation of bacteria found in car interiors and strategies to reduce the presence of potential pathogens. Biofouling 2014;40:339-344.

4. Scacchetti F. Desenvolvimento de um tecido multifuncional por acabamento para utilização em vestuário desportivo. Universidade do Minho Escola de Engenharia 2017:23-41.

5. Silva J, Ribeiro A, Costa S, Mello V, Lindenblatt C. Staphylococcus spp.: Incidência e surtos. Embrapa 2015;1:51

6. Brush L, Schmidt C, Perez M. Infecções estafilocócicas. Manual MSD: versão para Profissionais de Saúde 2019.;1:1-6.

7. Brush L. Infecções por Pseudomonas. Manual MSD: versão Saúde para a Família 2020;1:1-2.

8. Dantas T. Atividade antifúngica in vitro de timo sobre cepas do gênero Penicillium. Repositório UFPB 2013;1:22-29.

9. Menezes C, Perez A, Oliveira E. Cladosporium spp: Morphology. infections and pathogenic species. Acta Brasiliensis 2017;1:23-27.

10. Purwar R. Antimicrobial textiles. In: The Impact and Prospects of Green Chemistry for Textile Technology. Woodhead Publishing, 2019:281-306.

11. Lima M, Ramon A, Fonseca F, Gonçlvez C. A Química dos Saneantes em tempos de Covid-19: você sabe como isso funciona? Química Nova 2020;43: 668-678.

12. Fernandes P. Síntese. Caracterização e ação antimicrobiana de nanopartículas de prata. Locus UFV. 2014:22-27.

13. Ribeiro V. Desenvolvimento de compósitos antimicrobianos a base de Sebs/Pp aditivados com partículas de cobre. Lume 2019:19-25.

14. Benedito A, Silva F, Santos Í. Nanopartículas de prata: aplicações e impacto ambiental. Revista Acadêmica Oswaldo Cruz 2017;16:4-5.

15. Martins T, Chiapetta S, Carvalho L, Cassella R. Comparação da eficiência de diferentes técnicas (esgotamento e foulardagem) de fixação de permetrina em tecidos têxteis. Revista Virtual de Química 2015;7:1119-1129. 